\title{
The Positive Rates of Anti-HBs and Titers of Antibody after Hepatitis B Vaccination
}

\author{
Mi-Hwa Lee \\ Department of Medical Laboratory Science, Jinju Health College, Jinju 660-757, Korea
}

\section{$\mathrm{B}$ 형 간염백신 접종 후 항체형성률과 역가}

\author{
이미화 \\ 진주보건대학교 임상병리과
}

\begin{abstract}
The purpose of this study was to survey the anti-HBs positivity and titers of antibody in current students who received nationwide vaccination against Hepatitis B virus which targeted infants in 1995. The subjects were 262 students in Gyeongnam province from April 2014 to October 2014. The positive rate of anti-HBs was $55.3 \%$ (145 people) and the negative rate of anti-HBs was $44.7 \%$ (117 people). Positivity was shown to be higher in women than men. However, there was no statistically significant difference. Of the HBV-vaccinated subjects, $117(44.7 \%)$ had anti-HBs titer $<10$, which is judged to be negative, $126(47.8 \%)$ had anti-HBs titer $10-499.9 \mathrm{mIU} / \mathrm{mL}$, which is judged to be positive, and $22(7.3 \%)$ had anti-HBs titer more than $500 \mathrm{mlU} / \mathrm{mL}$. The rate of anti-HBs with lower titer $(10-99.9 \mathrm{mlU} / \mathrm{mL})$ was $62 \%$ in the positive group. Classifying the antibody titer according to age, the rate of anti-HBs positivity in titer with less than $100 \mathrm{mIU} / \mathrm{mL}$ was indicated to be $78.3 \%$ in cases of $19-20$ year old and $46.7 \%$ in $21-22$ year old, $52.3 \%$ in 23-24 year old. A case of the lower titer with 10-99.9 mIU/mL, showed significant difference according to age. As a result of research, the antibody titers is decreased depending on the passage of time. Hence, the checking of anti-HBs titer is needed after Hepatitis B vaccination and many healthy adults will need periodic boosters of hepatitis $B$ vaccine to maintain production of antibody to hepatitis B surface antigen.
\end{abstract}

Keywords: Anti-HBs, Titer, Booster

This is an Open Access article distributed under the terms of the Creative Commons Attribution Non-Commercial License (http://creativecommons.org/licenses/by-nc/4.0) which permits unrestricted non-commercial use, distribution, and reproduction in any medium, provided the original work is properly cited.

Copyright @ 2015 The Korean Society for Clinical Laboratory Science. All rights reserved.
Corresponding author: Mi-Hwa Lee Department of Medical Laboratory Science, Jinju Health College, Jinju 660-757, Korea Tel: 82-55-740-1846

E-mail:mhleejh@hanmail.net

Received: June 10, 2015 Revised: June 15, 2015 Accepted: June 15, 2015

\section{서 론}

B형 간염은 Blumberg 등(1965)에 의해 Ausralia원주민의 혈청 에서 처음 발견되었는데 만성간질환과 간세포성암의 주원인이 $\mathrm{B}$ 형 간염에 의한 것으로 보고되고 있다(Maynard,1990). B형 간염 에 대한 치료제가 개발되지 않은 현실에서 B형 간염백신 예방접종 은 매우 중요하다. Krugman 등(1971)은 HBV함유 혈청을 처리하 여 최초로 B형 간염백신을 만들었고 약 $70 \%$ 의 예방효과를 보고하 였다. $\operatorname{Kim}$ 등(1979)에 의해 우리나라에서도 자체 백신을 생산하기
에 이르렀으며 1983년부터 국가차원의 B형 간염백신 예방접종을 시작하였는데 1995년에는 영유아를 대상으로 간염백신 접종을 정 기예방접종 항목으로 도입하였다. 그 결과, 1980 년대 우리나라 국 민의 간염보균률은 $10 \sim 20 \%$ 이었으나 현재에 이르러서는 $5 \%$ 대로 감소되는 성과를 이루었다. 그러나 많은 연구보고에서 시간이 지남 에 따라 항체의 역가가 떨어진다고 하였는데 Jilg 등(1988)은 백신 접종 후 1 2년 사이에 항체의 역가가 급격히 떨어지며 4년 후에는 접종자의 약 $34 \%$ 에서 항체역가가 $10 \mathrm{mIU} / \mathrm{mL}$ 이하로 감소된다고 하였다. Williams 등(2003)도 백신접종 후 90\%의 접종자가 항체 
발현률을 보였으나 6개월 후에 $80.9 \%$ 로 감소하였다고 보고하였 다. 이와 같이 B형간염 백신의 항체 지속성과 역가 유지에 대한 보 고는 명확하지 않고 추가접종의 시기에 대해서도 분명하지 않다. 현재 우리나라에서 20 대 초반의 대학생들은 신생아 정기 예방접종 시작 전후에 태어난 세대인데 영유아기에 접종 받은 후 20 여년이 경과되었다. 이들이 초중고를 거치면서 실시한 학생 정기신체 검사 에는 B형 간염 항체 확인검사가 검진 항목에 없으며 다만 간염백신 추가접종을 권유하는 것에 그치고 있다. 영유아를 대상으로 국가차 원의 B형 간염 정기예방 접종 시작 후 장시간이 경과한 현 시점에서 B형 항체 보유율과 역가에 대한 조사는 그 의미가 크다고 하겠다. 본 연구에서는 20 대 대학생들의 B형 간염항체 양성률과 역가를 조 사하여 그 결과를 보고하고자 한다.

\section{재료 및 방법}

\section{1. 연구대상}

2014년 4월부터 2014년 10월까지 경남 소재 대학의 재학생 262 명을 대상으로 하였으며 추가접종자는 제외하였다. 채혈 후 혈 청을 분리하여 ADVIA Centaur XP (SIMENS, Tarrytown, NY, USA)를 이용하여 ADVIA Centaur CP Anti-HBs2 검사 kit로 B형 간염 표면항원에 대한 항체를 정량하였다. 간염항체의 양성판정은 역가 $10 \mathrm{mIU} / \mathrm{mL}$ 이상으로 정하였다.

\section{2. 자료처리 방법}

자료의 분석은 SPSS WIN 21.0 프로그램을 이용하여 분석하였 다. 연구대상자의 항체양성률과 역가를 교차분석, 독립표본 t검정,

Table 1. Distribution of subjects

\begin{tabular}{lccc}
\hline & \multicolumn{2}{c}{ Gender } & \multicolumn{1}{c}{$\begin{array}{c}\text { Total } \\
\text { Ages (yrs) }\end{array}$} \\
\cline { 2 - 3 } & $\begin{array}{c}\text { Female } \\
\text { No. (\%) }\end{array}$ & $\begin{array}{c}\text { Male } \\
\text { No. (\%) }\end{array}$ & \\
\hline $19 \sim 20$ & $105(40.1)$ & $58(22.1)$ & $163(62.2)$ \\
$21 \sim 22$ & $45(17.2)$ & $22(8.4)$ & $67(25.6)$ \\
$23 \sim 24$ & $2(0.8)$ & $30(11.5)$ & $32(12.2)$ \\
Total No. (\%) & $152(58.0)$ & $110(42.0)$ & $262(100.0)$ \\
\hline
\end{tabular}

일원변량분석을 통해 비교하였다. 모든 분석의 유의수준 $\alpha=.05$ 이다.

\section{결 과}

\section{1. 대상자의 분포}

연구대상은 262 명으로 여자 152 명(58.5\%), 남자 110 명(42.0\%) 이었다. 연령별 분포는 19 20세 연령군이 163명(62.2\%), 21 22 세 연령군이 67명(25.6\%), 23 24세 연령군은 32명(12.2\%)이었 다(Table 1).

\section{2. 성별에 따른 항체 양성률}

전체 대상자의 B형 간염항체 양성률은 $55.3 \%$ (145명)이었고 음 성률이 $44.7 \%$ (117명)이었다. 성별에 따라 양성률을 분류했을 때 여자가 $57.9 \%$ (88명), 남자는 $51.8 \%$ (57명)으로 여자가 남자보다 높았으나 통계적으로 유의한 차이는 없었다 $(p=0.329)$ (Table 2).

\section{3. 연령에 따른 항체 양성률}

항체 양성률을 연령에 따라 분류했을 때 19 20세 연령군은 47.9\% (78명), 21 22세 연령 군이 67.2\% (45명), 23 24세 연령 군이 69.7\% (21명)로 나타났다. 21 22세와 22 24세 연령군이 19 20세 연령군보다 높아 통계학적으로 유의한 차이를 보였다 $(p<.001)$ (Table 3).

\section{4. 항체 역가와 성별에 따른 비교}

역가 $10 \mathrm{mIU} / \mathrm{mL}$ 이상을 양성으로 판정하여 전체 대상자의 역가 를 비교하였을 때 역가 $10 ~ 99.9 \mathrm{mIU} / \mathrm{mL}$ 인 경우는 $34.4 \%$ (90명), $100 \sim 199.9$ mIU/mL는 8.4\% (22명), $200 \sim 499.9$ mIU/mL는

Table 2. Positive rates of anti-HBs by gender

\begin{tabular}{|c|c|c|c|c|}
\hline \multirow[b]{2}{*}{ Gender } & \multicolumn{2}{|c|}{ Anti-HBs } & \multirow[b]{2}{*}{$\chi^{2}(\mathrm{df})$} & \multirow[b]{2}{*}{$p$} \\
\hline & $\begin{array}{l}\text { Positive } \\
\text { No. (\%) }\end{array}$ & $\begin{array}{l}\text { Negative } \\
\text { No. (\%) }\end{array}$ & & \\
\hline Female & 88 (57.9) & $64(42.1)$ & 0.953 (1) & 0.329 \\
\hline Male & $57(51.8)$ & $53(48.2)$ & & \\
\hline Total (\%) & $145(55.3)$ & $117(44.7)$ & & \\
\hline
\end{tabular}

Table 3. Positive rates of anti-HBs by ages

\begin{tabular}{|c|c|c|c|c|c|}
\hline \multirow{2}{*}{ Ages (yrs) } & \multicolumn{3}{|c|}{ Anti-HBs } & \multirow{2}{*}{$\chi^{2}(\mathrm{df})$} & \multirow{2}{*}{$p$} \\
\hline & Positive No. (\%) & Negative No. (\%) & Total No. (\%) & & \\
\hline $19 \sim 20$ & $78(47.9)$ & $85(52.1)$ & $163(100.0)$ & $9.816(1)$ & 0.01 \\
\hline $21 \sim 22$ & $45(67.2)$ & $22(32.8)$ & $67(100.0)$ & & \\
\hline $23 \sim 24$ & $21(69.7)$ & $10(31.3)$ & $32(100.0)$ & & \\
\hline Total No. (\%) & $145(55.3)$ & $117(44.7)$ & $262(100.0)$ & & \\
\hline
\end{tabular}


Table 4. Anti-HBs titers by gender

\begin{tabular}{lccccc}
\hline Titer $(\mathrm{mlU} / \mathrm{mL})$ & Female No. (\%) & Male No. $(\%)$ & Total No. $(\%)$ & $\chi^{2}$ (df) & $p$ \\
\hline$\leq 9.9$ & $64(42.1)$ & $53(48.2)$ & $117(44.7)$ & $8.421(4)$ & 0.077 \\
$10 \sim 99.9$ & $60(39.5)$ & $30(27.3)$ & $12(10.9)$ & $22(8.4)$ & \\
$100 \sim 199.9$ & $10(6.6)$ & $9(8.2)$ & $14(5.3)$ & \\
$200 \sim 499.9$ & $5(3.3)$ & $6(5.5)$ & $19(7.3)$ & & \\
$\geq 500$ & $13(8.6)$ & $110(100.0)$ & $262(100.0)$ & & \\
Total No. (\%) & $152(100.0)$ & & & \\
\hline
\end{tabular}

Table 5. Anti-HBs titers by ages

\begin{tabular}{lcccccc}
\hline & \multicolumn{5}{c}{ Titer $(\mathrm{m} / \mathrm{U} / \mathrm{mL})$} \\
\cline { 2 - 6 } Ages (yrs) & $10 \sim 99.9$ & $100 \sim 199.9$ & $200 \sim 499.9$ & $\geq 500$ & $\chi^{2}(\mathrm{df})$ & $p$ \\
\hline $19 \sim 20$ & $58(78.3)$ & $8(10.2)$ & $4(5.12)$ & $8(10.2)$ & $27.807(4)$ & 0.001 \\
$21 \sim 22$ & $21(46.7)$ & $8(17.8)$ & $6(13.3)$ & $10(22.2)$ & & \\
$23 \sim 24$ & $11(52.3)$ & $6(28.5)$ & $4(19.0)$ & $1(4.7)$ & & \\
Total No. (\%) & $90(62.1)$ & $22(15.2)$ & $14(9.6)$ & $19(13.1)$ & & \\
\hline
\end{tabular}

$5.3 \%$ (14명), $500 \mathrm{mIU} / \mathrm{mL}$ 이상은 7.3\% (19명)로 나타났다. 음성 으로 판정된 역가 $9.9 \mathrm{mIU} / \mathrm{mL}$ 이하는 $44.7 \%$ (117명)이었다. 양성 으로 판명된 대상자의 $62 \%$ 가 가장 낮은 역가 범위인 10 99.9 $\mathrm{mIU} / \mathrm{mL}$ 에 속하였으며 역가가 높은 범위에서는 분포 비율이 매우 낮았다. 성별에 따라 비교했을 때 역가 $10 \sim 99.9 \mathrm{mIU} / \mathrm{mL}$ 범위에 서 여자가 $39.5 \%$ (60명), 남자는 $27.3 \%$ (30명)로 나타나 남자보다 여자가 역가가 낮은 범위에 많이 분포되어 있음을 알 수 있었다. 그 러나 전체적인 역가비교에서 성별에 따라 통계적으로 유의한 차이 는 없는 것으로 나타났다 $(p=0.077$ ) (Table 4).

\section{5. 연령에 따른 항체역가}

연령에 따라 분류하였을 때 역가 $10 ~ 99.9 \mathrm{mIU} / \mathrm{mL}$ 범위에서 19 20세 연령군이 78.3\% (58명), 21 22세 연령군 46.7\% (21 명), 23 24세 연령군이 52.3\% (11명)로 분포되어 19 20세 연령 군이 다른 연령군에 비해 통계적으로 유의하게 낮았다. 역가 100 $199.9 \mathrm{mIU} / \mathrm{mL}$ 와 200 $499.9 \mathrm{mIU} / \mathrm{mL}$ 범위에서는 연령이 높아짐에 따라 분포 비율이 증가하는 경향을 나타냈다. 각 연령군의 개별적인 역가 분포를 살펴보았을 때, 모든 연령군이 가장 낮은 역가인 $10 ~$ $99.9 \mathrm{mIU} / \mathrm{mL}$ 범위에 높은 분포를 나타냈고 $100 \mathrm{mIU} / \mathrm{mL}$ 이상의 높은 역가 범위에서는 낮은 분포를 나타냈다 $(p<.001)$ (Table 5).

\section{고 찰}

우리나라의 간염 보균자는 전 국민의 약 $5 \%$ 정도이며 약 300 만 명으로 추산하고 있다. 우리나라는 1983년도에 전염병 예방법 시 행령에 의거하여 B형 간염예방접종을 실시하였으며 1992년부터
는 대한소아학회에서 기본 예방접종으로 분류하여 시행하고 있다. 여러 연구에서 B형 간염백신 접종 후 항체 형성률은 연령과 면역력 에 따라 차이가 있다고 하는데(Stevens 등,1980; Zachoval 등, 1984), 소아는 성인 보다 항체 형성률이 높고 항체의 역가도 더 높 다고 하였다(Denis 등, 1984; Shaw 등, 1989). 그러나 시간이 갈수 록 역가가 떨어져 성인의 $60 \%$ 에서 접종 후 7 년째에는 항체를 측정 할 수 없도록 역가가 소실된다고 하였다(Shiff 등,1993; Crosnier 등, 1981). Kim 등(1979)은 백신접종 후 1년째에는 항체 양성률이 $96 \%$ 였으나 2년째에 70\%로 감소된다고 보고하였다. Seo(2003)도 연령이 증가할수록 항체가 감소되어 간염예방 접종 후 시간이 지 남에 따라 항체양성률이 저조한 것을 확인하였다고 한다. 예방접종 후 간염 항체의 양성률의 기준은 혈청 Anti-HBs역가 $10 \mathrm{mIU} / \mathrm{mL}$ 이상이나 나라마다차이가 있어서 영국의 경우 $100 \mathrm{mIU} / \mathrm{mL}$ 을 기 준점으로 잡고, $10 \sim 100 \mathrm{mIU} / \mathrm{mL}$ 인 경우는 저반응, $10 \mathrm{mIU} / \mathrm{mL}$ 이하인 경우는 무반응자로 분류한다(Goudeau 등, 1983). 본 연구 에서는 항체 역가의 기준을 $10 \mathrm{mIU} / \mathrm{mL}$ 로 정하였으나 일반적인 양 성기준인 $10 \mathrm{mIU} / \mathrm{mL}$ 는 위양성률이 많고 검사법에 따라 음성의 빈 도가 많으므로 역가의 안정성을 위해 상향조정을 고려하는 것이 바 람직하겠다. 항체 유지 기간은 예방접종 후 최고 항체역가에 비례 한다고 알려져 있는데(Dienstag 등, 1984) 많은 연구에서 B형 간염 백신의 면역성과 안정성은 인정하고 있으나 백신 접종후의 항체유 지 지속기간과 항체의 역가 및 추가접종 시기나 접종량 등에 대한 명료한 규정이 없다. Lin 등(2003)은 B형 간염 항체 백신 접종 후 10 $\mathrm{mIU} / \mathrm{mL}$ 이상인 경우는 바이러스에 노출된다하더라도 항체가가 급속히 상승하여 방어를 하며 면역기억 능력이 15년간 유지 된다 고 하였다. 그러나 백신접종 후 최대 항체가를 정해 놓지 않는다면 
면역 기억능력이 있는지의 여부를 알 수 없다는 연구가 있다 (European Consensus Group, 2000). Goudeau 등(1983)은 건 강인의 백신 접종 후 7년간의 추적연구에서 항체역가 $30 \mathrm{mIU} / \mathrm{mL}$ 인 경우 추가접종이 필요하며 건강인의 경우 5 년마다 추가접종 하 는 것이 바람직하다고 하였다. 본 연구에서 소아의 간염예방 접종 사업이 진행된 1995년도를 기준으로 1990년도에서 1995년도까 지의 출생자인 만 19 세-24세의 대학생을 대상으로 간염항체 여부 를 조사한 바, 최초 접종 후 약 20 년이 지난 시점에서 항체 양성률이 $55.3 \%$ 를 나타내었다. 역가를 분석한 결과, 양성을 나타낸 학생들 의 62\%가 역가 $10-99.9 \mathrm{mIU} / \mathrm{mL}$ 범위에 속하여 매우 낮은 역가를 보유하고 있었으며 역가 $100 \mathrm{mIU} / \mathrm{mL}$ 이상은 $38 \%$ 에 불과하였다. $\mathrm{Seo}(2003)$ 도 제주지역의 소아와 청소년의 B형간염 항체연구에서 19-20세 연령층의 항체 형성률은 $59.5 \%$ 라고 보고하여 본 연구와 유사한 결과를 나타냈다. 성별에 따른 연구로는 Kim 등(1979)과 Stevens 등(1980)이 B형간염 예방접종 후의 항체역가는 여자가 남 자보다 높고 연령이 낮을수록 더욱 높다고 보고하였는데 Dienstag 등(1984)은 남녀에 차이가 없다고 하였다. 본 연구에서도 여자의 anti-HBs 양성률이 $57.9 \%$ 로 남자의 $51.8 \%$ 보다 높게 나왔으나 통 계적으로 유의한 차이가 없었다. 연령에 따라 역가 차이를 비교했 을 때 19 20세 연령군이 21세 이상의 연령군 보다 낮은 역가를 나 타냈다. 이는 연령군간에 나이 차이가 적고 각 연령군의 측정 대상 자수가 일정하지 않았으며 인원수가 적은 군에서 역가가 높게 나오 는 경우가 발생하면 상대적으로 높은 분포에 속하게 되는 것으로 생각되어 추후 고려해야할 사항으로 사료된다. 초중고생을 대상으 로 한 우리나라의 학생건강검사 항목은 중학교 1학년에서 B형 간 염 항원 검사를 한차례 할 뿐 전 학령기간 동안 항체 확인검사는 전 혀 실시하지 않고 있는 실정이다. 시간이 감에 따라 항체의 역가가 떨어져 음성으로 전환될 수 있으며 양성으로 판정된다 하더라도 대 부분 $100 \mathrm{mIU} / \mathrm{mL}$ 이하의 역가를 나타낸다면 우리나라의 젊은 층 의 건강관리에 문제가 있다고 하겠다. 소아시기에 접종 후 일정 기 간이 지나면 항체 확인검사를 하고 국가차원에서 추가접종을 하도 록 독려해야 할 것으로 사료된다.

\section{요 약}

우리나라는 1995년부터 영유아를 대상으로 국가차원의 B형 간 염백신 예방접종을 시작하였다. 현재 우리나라의 20 대 대학생들은 신생아 정기 예방접종 시작 전후에 태어난 세대이며 영유아기에 접 종을 받고 20 여년이 경과되었다. 영유아를 대상으로 B형 간염 정기 예방 접종 시작 후 장시간이 경과한 현 시점에서 B형 항체 보유율과 역가에 대한 확인은 매우 중요하다. 본 연구에서는 20 대 대학생들 의 B형 간염항체 양성률과 역가를 조사하였으며 연구대상은 2014
년 4월부터 2014년 10월까지 경남 소재 대학의 대학생 262명을 대 상으로 하였다. 추가접종자는 제외하였으며 간염항체의 양성판정 은 $10 \mathrm{mIU} / \mathrm{mL}$ 이상으로 정하였다. 연구결과, B형 간염 항체의 양 성률은 $55.3 \%$ ( 145 명)이었고 음성률은 $44.7 \%$ (117명)이었다. 성 별에 따라 양성률을 분류했을 때 여자는 $57.9 \%$ (88명), 남자는 $51.8 \%$ (57명)로 여자가 남자보다 높았으나 통계적으로 유의한 차 이는 없었다. 연령에 따라 역가 차이를 비교했을 때 19 20세 연령 군이 21세 이상의 연령군 보다 낮은 역가를 나타냈다. 이는 본 연구 의 연구대상자들이 연령군간에 나이 차이가 적고 각 연령군의 측정 대상자수가 일정하지 않았으며 인원수가 적은 군에서 역가가 높게 나오는 경우가 발생하면 해당 연령군이 상대적으로 역가가 높은 분 포에 속하게 되는 것으로 생각되어 추후 고려해야할 사항으로 사료 된다. 양성으로 판명된 연구대상자의 $62 \%$ 가 역가의 하한선인 10-99.9 mIU/mL의 낮은 역가를 나타냈다. 소아기에 접종 후 일정 기간이 지나면 항체 확인검사를 하고 국가차원에서 추가접종을 추 진해야 할 것으로 사료된다.

Acknowledgements: 본 연구는 2014학년도 진주보건대학교 교 내연구비에 의해 연구되었으며 이에 감사드립니다.

Funding: 진주보건대학교 교내연구비

Conflict of interest: None

\section{References}

1. Blumberg BS, Alter HJ. A new antigen in lewkemia sera. JAMA. 1965,191:541-546.

2. Crosnier J, Jungers P, Courouce AM, Laplanche A. Randomized placebo controlled trial of hepatitis B surface antigen vaccine in french haemodialysis unitis: II hemodialysis patients. Lancet 1981,1:797-801.

3. Denis F, Mounier M, Hessel L, Michel JP, Gualde N. Hepatitis B vaccination in the elderly. J Infect Dis. 1984,149:1019-1024.

4. Dienstag JL, Werner BG, Polk BF, Snydman DR, Craven DE, et al. Heptitis vaccine in health carepersonal: Safety, immunigenecity and indicators of efficacy. Ann Inter Med. 1984,101: 34-38.

5. European Consensus Group on Hepatitis B immunity. Are booster immunisations needed for lifelong hepatitis B immunity. Lancet. 2000,335:561-565.

6. Goudeau A, Dubois F, Barin G, Dubois MC, Coursaget P: Hepatitis B vaccine: Clinical trials high risk settings in France (September 1975-September 1982). Develop Biol Standard. 1983,54:267-278.

7. Jilg W, SChmit M, Deinhard F. Persistence of specifics antibodies after hepatitis B vaccination. J hepatology. 1988,201207.

8. Kim JR. Study of hepatitis B vaccine. JKMA. 1979,22:10131025 . 
9. Krugman S, Giles JP, Hammond JU. Viral hepatitis type B (MS2strain)studies on active immunization. JAMA. 1971,217:41-55.

10. Lin YC, Chang MH, NI YH, Hsu HY, Chen DS. Long-term immunogenicity and efficacy of universal hepatitis B virus vaccination in Taiwan. J Infect Dis. 2003,17:134-138.

11. Maynard JE. Hepatitis B. Global importance and need for control. Vaccine. 1990,8:18-20.

12. Seo JH. Hepatitis B surface antigen and antibody positive rates of Children and adolescents in Jeju. Korean Hepatol. 2003, 9:304-314.

13. Shaw FE, GuessHA, Roets JM, Mohr FE, Coleman PJ, Mandel EJ, et al. Effect of amnestic injection site, age and smoking on immune response of preterm infants to hepatits B vaccine. Vaccine.
1989,7:425-430.

14. Shiff L, Shiff ER. Disease of the liver. 1993, p554-556. JB Lippincott commpany, Philadelphia.

15. Stevens CE, Szmuness W, Goodman AI, Weseley SA, Fotino M. Hepatitis B vaccine: Immune responses in hemodialysis patients. Lancet. 1980,2:1211-1216.

16. Williams IT, Goldstein ST, Tufa J, Tauilli S, Margolis HS, Mahoney FJ. Long term antibody response to hepatitis B vaccination beginning at birth and to subsequent booster vaccination. Pediatr Infect Dis J. 2003,22:157-163.

17. Zachoval R, Jilg W,Lorbeer B, Schmidt M. Passive/active immunization against hepatitis B. B. J infect Dis. 1984,150: 112-118. 